\title{
The Important Role of Graft Organization at the Vascular Prosthetic Anastomosis
}

\author{
HISAo SASAKI \\ The Second Department of Surgery, Tohoku University \\ School of Medicine, Sendai 980
}

\begin{abstract}
SASAKI. H. The Important Role of Graft Organization at the Vascular Prosthetic Anastomosis. Tohoku J. exp. Med., 1980, 132 (4), 405-411 — The vascular anastomosis free of suture was made by using an absorbable suture and its tensile strength was compared with that of non-absorbable suture anastomosis. 29 adult mongrel dogs weighing 7.5 to $13.5 \mathrm{~kg}$ were used. Two kinds of vascular anastomosis were performed, that is, artery-to-artery anastomosis and vascular prosthetic graft to artery anastomosis. They were made in the right carotid artery and the abdominal aorta, respectively. Two kinds of suture were used for the vascular anastomosis, i.e., polyglycolic acid suture as an absorbable suture and TEVDEK suture as a non-absorbable suture. The tensile strength of anastomosis was measured by a self-made tensiometer. The following results were obtained: In the artery-to-artery anastomosis, the loss of the strength of suture did not weaken the anastomosis, whereas in the vascular prosthetic anastomosis, the loss of the tensile strength of suture weakened the vascular prosthetic anastomosis. However, well organized fibrous tissues surrounding the vaseular prosthesis were strong enough to hold against the blood pressure.—- graft organization; strength of vascular anastomosis; absorbable suture; anastomotic aneurysm
\end{abstract}

Even after the healing process of the anastomosis has been completed aneurysm may occur at the anastomotic site of vascular prosthesis. There are many factors which may be involved in the pathogenesis of anastomotic aneurysm and their roles are controversial (Gaylis et al. 1959; Moore and Hall 1970; Szilagyi et al. 1975; Knox 1976; Sasaki 1977). These include the weakness of suture material, the integrity of the wall of recipient vessel, the way of the anastomosis, infection of the anastomosis, etc. In the pathogenesis of non-infected anastomotic aneurysms, the weakness of suture material is considered as one of the most important factors and the synthetic suture has been recommended rather than silk suture.

Our vascular surgical cases for the past 10 years included 14 cases of anastomotic aneurysms; silk sutures were used in 8 cases and synthetic sutures were used in the remaining 6 cases (Sasaki 1977). The histological study revealed poor organization of vascular graft in 6 cases. It was considered that the anastomotic aneurysm could not be eliminated by the strength of suture alone. On the other hand, in some cases the organized tissue suggested to play a role as

Received for publication, August 3, 1979.

Part of this paper was presented at the Meeting of the Xth International Congress of Angiology, Tokyo, 1976. 
the major reinforcing material around the vascular anastomosis. Namely, the dissolution of suture material may not be the cause for the anastomotic aneurysm. In order to confirm this hypothesis, the present animal experiments were conducted.

\section{Materials and Methods}

Twenty-nine adult mongrel dogs, weighing 7.5 to $13.5 \mathrm{~kg}$, were used. All operative procedures were performed using sterile techniques. The vascular anastomoses were performed at the right carotid artery and the infrarenal abdominal aorta. The animals were anesthetized with sodium pentobarbital $30 \mathrm{mg} / \mathrm{kg}$ and heparin $1 \mathrm{mg} / \mathrm{kg}$ i.v. The right carotid artery was resected $2 \mathrm{~cm}$ long and it was sutured back into the position using endto-end anastomosis by an absorbable No. $6-0$ polyglycolic acid suture (PGA) at the proximal anastomosis and a non-absorbable synthetic No. 6-0 TEVDEK ${ }^{\circ}$ suture at the distal anastomosis. The infrarenal abdominal aorta was removed and replaced with a $1.5 \mathrm{~cm}$ Edwards woven teflon vascular prosthesis. The proximal anastomosis was performed with No. 4-0 TEVDEK suture (abbrev. TEVDEK anastomosis), and the distal TEVDEK anastomosis was performed with No. 4-0 PGA suture (abbrev. PGA anastomosis). Four dogs each were sacrificed on the 5th, 10th, 20th, 30th, 45th and 60th day after operation. The tensile strength of these anastomoses was measured with a selfmade instrument (Sasaki 1977) (Fig. 1). In order to know the change of the tensile strength of PGA suture in biological tissue, the tensile strength of No. 4-0 PGA suture which was implanted subcutaneously in a mongrel dog for a period of 5 to 50 days was measured (Fig. 2). Angiography was performed in all dogs before autopsy.

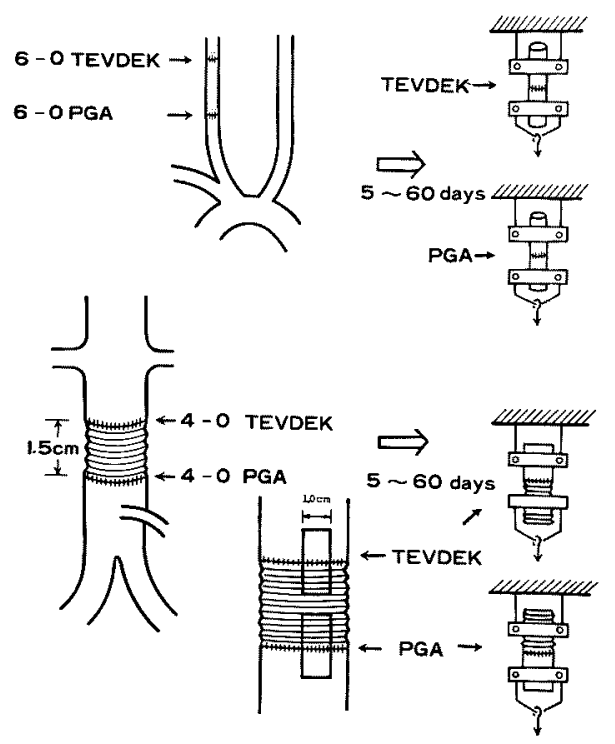

Fig. 1. Method of measurement of the tensile strength in vascular anastomosis.

Anastomoses were made on the right carotid artery and abdominal aorta. The tensile strength of these anastomoses after 5 to 60 postoperative days were measured with a selfmade instrument.

TEVDEK, non absorbable suture; PGA, absorbable suture. 


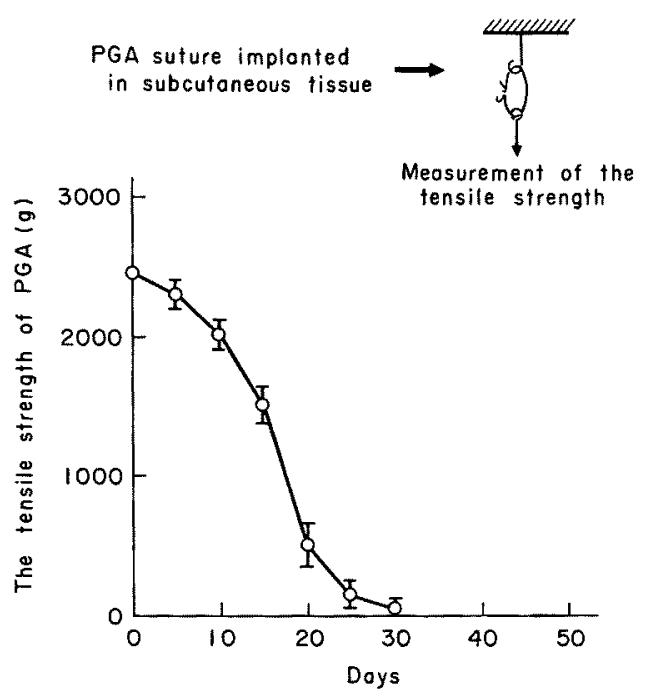

Fig. 2. The change of the tensile strength of PGA suture implanted in the subcutaneous tissue of dogs.

\section{RESULTS}

The examination was performed in three ways, i.e., by angiography, and by measuring the strength of anastomosis between the arteries, and that between the prosthesis and artery.

The strength of PGA suture. No. 4-0 PGA suture had lost all its strength by the 30 th day. The tissue reaction around the PGA suture was very little. It was considered, therefore, that the influence of suture would be lost at the PGA anastomosis after 30 days (Fig. 2).

Angiography. Four of 29 cases of transplantation of the prosthesis into the aorta showed occlusion of the prosthesis. However, none of the cases developed anastomotic aneurysms.

The strength of artery-to-artery anastomosis. The artery-to-artery anastomosis was made at the right carotid artery, and its strength was measured. The strength of the anastomosis was shown as the percentage of the tensile strength to that of the left intact carotid artery. The strength of TEVDEK anastomosis was $72 \%$, and that of the PGA anastomosis was $67 \%$ on the 5 th day after operation, which became stronger up to almost $100 \%$ by the 60 th day after operation. There was no statistical difference between TEVDEK anastomosis and PGA anastomosis. After 30 days when the PGA suture was absorbed, the strength of PGA anastomosis was held as high as that of TEVDEK anastomosis (Table 1, Fig. 3).

The strength of prosthetic graft-to-artery anastomosis. The prosthetic graft to artery was made at the abdominal aorta and its strength was measured. The strength of the anastomosis was shown as the percentage of the tensile strength to that of the intact thoracic aorta. 
TABLE 1. The results of artery-to-artery anastomosis

\begin{tabular}{|c|c|c|c|c|c|c|}
\hline \multirow{2}{*}{$\begin{array}{l}\text { Dog } \\
\text { No. }\end{array}$} & \multirow{2}{*}{$\begin{array}{l}\text { Period of } \\
\text { observation } \\
\text { (days) }\end{array}$} & \multirow{2}{*}{$\begin{array}{l}\text { Tensile } \\
\text { strength of } \\
\text { the left } \\
\text { carotid } \\
\text { artery } \\
(\mathrm{kg} / \mathrm{cm})\end{array}$} & \multicolumn{2}{|c|}{$\begin{array}{l}\text { Tensile strength of } \\
\text { anastomosis }\end{array}$} & \multirow{2}{*}{$\begin{array}{l}\text { Tensile strength } \\
\text { of TEVDEK } \\
\text { anastomosis } \\
\text { (percent of the } \\
\text { left carotid } \\
\text { artery) }\end{array}$} & \multirow{2}{*}{$\begin{array}{l}\text { Tensile strength } \\
\text { of PGA anas- } \\
\text { tomosis (percent } \\
\text { of the left } \\
\text { carotid artery) }\end{array}$} \\
\hline & & & $\begin{array}{l}\text { TEVDEK } \\
\text { anastomosis } \\
(\mathrm{kg} / \mathrm{cm})\end{array}$ & $\begin{array}{c}\text { PGA } \\
\text { anastomosis } \\
(\mathrm{kg} / \mathrm{cm})\end{array}$ & & \\
\hline 6211 & 5 & 2.00 & 1.45 & 1.45 & 72.5 & 72.5 \\
\hline 6231 & & 2. 00 & 1.65 & 1.65 & 82.5 & 82.5 \\
\hline 6269 & & 2.10 & 1.30 & 1.00 & 61.9 & 47.5 \\
\hline 6278 & & & - & - & $($ Mean $72.3 \pm 10.3)$ & (Mean 67.5 \pm 18.0$)$ \\
\hline 5704 & 10 & - & - & - & - & - \\
\hline $575^{7}$ & & - & - & - & - & - \\
\hline $583^{2}$ & & 3.50 & 3.10 & 2. 10 & 88.5 & 60.0 \\
\hline $605^{0}$ & & - & - & - & - & $\begin{array}{l}- \\
-\end{array}$ \\
\hline 5497 & 20 & 2.30 & 2.05 & 2.38 & 89.1 & 103.4 \\
\hline 5955 & & 2. 20 & 1.80 & 2.00 & 81.8 & 90.9 \\
\hline 6055 & & 3. 00 & 1.70 & 1.85 & 56.5 & 61.6 \\
\hline 6099 & & 2.42 & 2.28 & 1.60 & $\begin{array}{l}94.2 \\
(\text { Mean } 80.4 \pm 16.6)\end{array}$ & $\begin{array}{l}66.1 \\
(\text { Mean } 80.5 \pm 19.9)\end{array}$ \\
\hline 5340 & 30 & 2.42 & 2.05 & 2.28 & 84.7 & 94.2 \\
\hline 5441 & & 2.25 & 1.89 & 1.90 & 84.0 & 84.4 \\
\hline 5487 & & 2.34 & 1.99 & 2.60 & 85.0 & 88.0 \\
\hline 5742 & & 2.52 & 2.10 & 2.27 & $\begin{array}{c}83.3 \\
\text { (Mean } 84.3 \pm 6.7 \text { ) }\end{array}$ & $\begin{array}{c}90.0 \\
\text { (Mean } 89.2 \pm 4.0 \text { ) }\end{array}$ \\
\hline 5356 & 45 & 2.85 & 3.20 & 2.15 & 112.2 & 75.4 \\
\hline 5555 & & 2.40 & 2.20 & 2.70 & 91.6 & 112.5 \\
\hline 5748 & & 2. 60 & 2.30 & 1.90 & 88.4 & 73.0 \\
\hline 5769 & & 2. 80 & 2.15 & 2.40 & $\begin{array}{ll} & 76.7 \\
\text { (Mean } 92.2 \pm 14.7 \text { ) }\end{array}$ & $\begin{array}{c}85.7 \\
(\text { Mean } 86.6 \pm 18.0)\end{array}$ \\
\hline 5343 & 60 & 1.85 & 2.30 & 1.75 & 124.3 & 94.5 \\
\hline 5375 & & 2.00 & 2.63 & 2. 28 & 131.5 & 114.0 \\
\hline 5444 & & 2.20 & 1.99 & 2.18 & 90.8 & 99.1 \\
\hline 5492 & & 3.10 & 3.70 & 2.75 & $\begin{array}{l}119.3 \\
(\text { Mean } 116.4 \pm 17.8)\end{array}$ & $\begin{array}{c}88.7 \\
(\text { Mean } 99.0 \pm 10.8)\end{array}$ \\
\hline
\end{tabular}

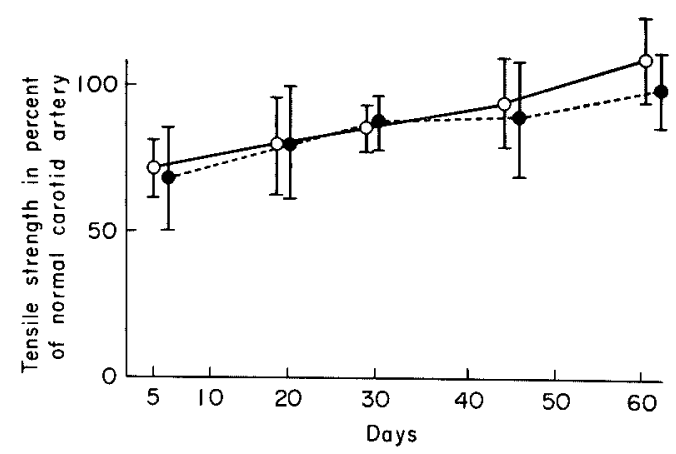

Fig. 3. The change of the strength at artery-to-artery anastomosis during a 60 days duration. o-0, 6-0 TEVDEK; •--•, 6-0 PGA. 
TABLE 2. The results of prosthetic graft-to-artery anastomosis

\begin{tabular}{|c|c|c|c|c|c|c|}
\hline \multirow{2}{*}{$\begin{array}{l}\text { Dog } \\
\text { No. }\end{array}$} & \multirow{2}{*}{$\begin{array}{l}\text { Period } \\
\text { of } \\
\text { obser- } \\
\text { vation } \\
\text { (days) }\end{array}$} & \multirow{2}{*}{$\begin{array}{l}\text { Tensile } \\
\text { strength of } \\
\text { the intact } \\
\text { thoracic } \\
\text { aorta } \\
(\mathrm{kg} / \mathrm{cm})\end{array}$} & \multicolumn{2}{|c|}{$\begin{array}{l}\text { Tensile strength of } \\
\text { anastomosis }\end{array}$} & \multirow{2}{*}{$\begin{array}{l}\text { Tensile strength } \\
\text { of TEVDEK } \\
\text { anastomosis } \\
\text { (percent of the } \\
\text { thoracic aorta) }\end{array}$} & \multirow{2}{*}{$\begin{array}{l}\text { Tensile strength of } \\
\text { PGA anastomosis } \\
\text { (percent of the } \\
\text { thoracic aorta) }\end{array}$} \\
\hline & & & $\begin{array}{l}\text { TEVEDK } \\
\text { anastomosis } \\
(\mathrm{kg} / \mathrm{cm})\end{array}$ & $\begin{array}{c}\text { PGA } \\
\text { anastomosis } \\
(\mathrm{kg} / \mathrm{cm})\end{array}$ & & \\
\hline 6211 & \multirow[t]{4}{*}{5} & 1.01 & 1.09 & 2.32 & 107 & 229 \\
\hline 6231 & & 1.15 & 2.65 & 1.80 & 230 & 150 \\
\hline 6269 & & 1.00 & 0.75 & 0.50 & 70 & 50 \\
\hline 6278 & & 1.10 & 1.45 & 1.65 & $\begin{array}{c}131 \\
\text { (Mean } 134 \pm 68 \text { ) }\end{array}$ & $\begin{array}{c}197 \\
(\text { Mean } 158 \pm 78)\end{array}$ \\
\hline 5704 & \multirow[t]{4}{*}{10} & 1.06 & 2.07 & 2.16 & 195 & 204 \\
\hline 5757 & & 1.05 & 2.45 & 2.40 & 233 & 228 \\
\hline 5832 & & 1.00 & 2.60 & 2.70 & 260 & 270 \\
\hline 6050 & & 0.80 & 2.00 & 2.60 & $\begin{array}{c}250 \\
\text { (Mean } 234 \pm 28 \text { ) }\end{array}$ & $\begin{array}{c}325 \\
\text { (Mean } 256 \pm 53 \text { ) }\end{array}$ \\
\hline 5497 & \multirow[t]{4}{*}{20} & 1.30 & 2.25 & 2.05 & 173 & 157 \\
\hline 5955 & & 0.70 & 2.35 & 0.65 & 335 & 92 \\
\hline 6055 & & 1.23 & 2.30 & 1.65 & 187 & 134 \\
\hline 6099 & & 1.00 & 3.50 & 1.90 & $\begin{array}{c}350 \\
\text { (Mean } 261 \pm 94 \text { ) }\end{array}$ & $\begin{array}{c}190 \\
(\text { Mean } 143 \pm 40)\end{array}$ \\
\hline 5340 & \multirow[t]{4}{*}{30} & 1.06 & 1.20 & 1.15 & 120 & 115 \\
\hline 5441 & & 0.95 & 1.70 & 0.92 & 178 & 96 \\
\hline 5481 & & 1.20 & 1.99 & 1.48 & 160 & 123 \\
\hline 5742 & & 1.10 & 1.65 & 1. 22 & $\begin{array}{c}150 \\
(\text { Mean } 152 \pm 24)\end{array}$ & $\begin{array}{c}110 \\
(\text { Mean } 111 \pm 11)\end{array}$ \\
\hline 5356 & \multirow[t]{4}{*}{45} & 0.80 & 1.95 & 1.10 & 211 & 161 \\
\hline 5555 & & 1.30 & 2.75 & 2.10 & 243 & 137 \\
\hline 5748 & & 1.90 & 2.60 & 2.00 & 136 & 105 \\
\hline 5769 & & 1.65 & 2.60 & 2.15 & $\begin{array}{c}157 \\
\text { (Mean } 187 \pm 48)\end{array}$ & $\begin{array}{c}130 \\
\text { (Mean } 133 \pm 23 \text { ) }\end{array}$ \\
\hline 5343 & \multirow[t]{4}{*}{60} & 1.42 & 0.90 & 0.60 & 204 & 42 \\
\hline 5375 & & 1.45 & 2.95 & 2.88 & 203 & 198 \\
\hline 5444 & & 1.90 & 1.95 & 1.80 & 155 & 94 \\
\hline 5492 & & 1.73 & 2.50 & 2.45 & (Mean 174 176 231$)$ & $\begin{array}{c}141 \\
(\text { Mean } 144 \pm 52)\end{array}$ \\
\hline
\end{tabular}

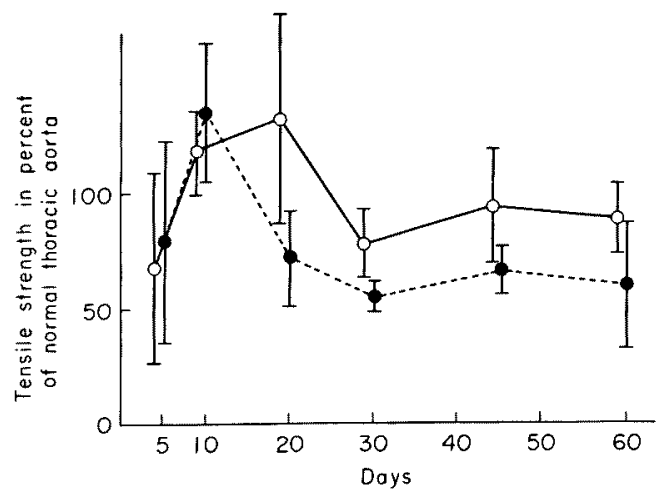

Fig. 4. The change of the strength at vascular prosthetic anastomosis during a 60 day duration. o-o, 4-0 TEVDEK; 
There was no difference between the strength of TEVDEK anastomosis and that of PGA anastomosis by the 10th day after operation. The strength of both TEVDEK anastomosis and PGA anastomosis was $134 \%$ on the 5th day after operation, while it increased up to $234 \%$ and $256 \%$ on the 10 th day, respectively. On the 20th day the strength of PGA anastomosis decreased to $134 \%$, but that of TEVDEK anastomosis which was made by using the non-absorbable synthetic TEVDEK suture increased up to $261 \%$. After the 30th day, the strength of TEVDEK anastomosis and PGA anastomosis became consistent, but the strength of PGA anastomosis fell to $2 / 3$ of that of TEVDEK anastomosis. However, PGA anastomosis retained its strength equal to that of the intact thoracic aorta after the 30th day when PGA suture lost all of its strength (Table 2, Fig. 4).

\section{Discussion}

Lowenberg and Shumacker (1949) measured the rate of healing after reparing the dog carotid artery and found a curve of healing approximating that of other sutured tissue. In the present experimental study, the vascular anastomosis was made by using an absorbable PGA suture. The comparison between the absorbable and non-absorbable suture anastomoses revealed that the rates of healing of both kinds of anastomosis were almost similar to that reported by Lowenberg and Shumacker (1949). But, the rate of healing of prosthetic graft-toartery anastomosis was different from that of artery-to-artery anastomosis. In the prosthetic graft-to-artery anastomosis, it had only two-thirds of the strength of non-absorbable suture anastomosis after the absorbable suture was absorbed.

Causative factors of anastomotic aneurysms other than infection have been postulated (Gaylis et al. 1959; Moore and Hall 1970; Szilagyi et al. 1975; Knox 1976; Sasaki 1977). Knox (1976) emphasized that suture material, end-to-side anastomosis, proximity of the anastomosis to a joint and intimectomy of the recipient artery should be taken into consideration. Moore and Hall (1970) showed that anastomotic aneurysms in 25 cases were due to prosthetic graft. Silk suture had been used in almost all of these cases, and when anastomotic aneurysms occurred, silk sutures were found either broken or dissolved. Szilagyi et al. (1975) indicated that the most important causative factors were structural weakness of the parent artery, hypertension, mechanical stress of the suture line, defect of the prosthesis and healing complication of surgical incision. These factors may be divided into two main groups, i.e., one is the weakness of structure at the suture line which includes arterial wall, prosthesis and suture material, and the other is the mechanical stress which includes hypertension and joint movement.

In general, the healing of suture line between graft and artery begins at the outer layer of fibrin, which is soon replaced by the connective tissue, and the inner line is covered by a pseudointima. It has been thought that the tensile strength of these connective tissues is quite low and the integrity of an anastomosis is dependent on the suture material (Warren and McCombs 1965; Moore and Hall 1970; Szilagyi et al, 1975; Chavez 1976; Knox 1976). By morphologic study on 
the arterial prosthesis, Warren and McCombs (1965) pointed out that the surrounding fibrin tissue was not strong enough to support arterial pressure.

This experimental study might support partially that the fault of suture material could cause anastomotic aneurysm. However, this study showed that the strength of the surrounding fibrin tissue was greater than expected, as none of the cases developed anastomotic aneurysms and the strength of absorbable suture anastomosis kept almost the same value as that of the intact thoracic aorta. Therefore, it is thought that the surrounding fibrin tissue plays a role in reinforcing an anastomotic line. The concomitant presence of the two factors, that is, the decrease in the tensile strength of vascular sutures and the poor organization of vascular prosthesis, is considered to lead to the occurrence of anastomotic aneurysm. We should take advantage of the role of organized tissue as a reinforcing material to prevent an anastomotic aneurysm of vascular prosthetic graft.

\section{References}

1) Chavez, C.M. (1976) False aneurysms of the femoral artery. Ann. Surg., 183, 694-700.

2) Gaylis, H., Corvese, W.P., Linton, R.R. \& Shaw, R.S. (1959) The rate of healing of arterial autografts. Surgery, 45, 41-58.

3) Knox, W.G. (1976) Peripheral vascular anastomotic aneurysms. Ann. Surg., 183, 120123.

4) Lowenberg, R.I. \& Shumacker, H.B., Jr. (1949) Experimental studies in vascular repair. II. Strength of arteries repaired by end to end suture, with some notes on growth of anastomosis in young animals. Arch. Surg., 59, 74-83.

5) Moore, W.S. \& Hall, A.D. (1970) Late suture failure in the pathogenesis of anastomotic false aneurysms. Ann. Surg., 172, 1064-1068.

6) Sasaki, H. (1977) Clinical and experimental study on the genesis of aneurysmal formation following transplantation of vascular prosthesis. Nippon Geka-Gakkaishi, 78, 853-897. (Japanese)

7) Szilagyi, E.D., Smith, R.F., Eliott, J.D., Hageman, J.H. \& Dallolmo, C.A. (1975) Anastomotic aneurysms after vascular reconstruction; problems of incidence, etiology and treatment. Surgery, 78, 800-816.

8) Warren, R. \& McCombs, H.L. (1965) Morphologic studies on plastic arterial prostheses in humans. Ann. Surg., 161, 73-82. 